\title{
Pursuing Balance: Analysis of the PRC's Implementation of Trade and Investment SDGs in Cooperation With Leading Partners From the Least Developed Countries ${ }^{1,2}$
}

\section{S. Mikhnevich}

Sergey Mikhnevich - PhD, Director of the Center for Multilateral Cooperation, Russian Union of Industrialists and Entrepreneurs; Senior Researcher, Center for International Institutions Research, Russian Presidential Academy of National Economy and Public Administration (RANEPA), 11 Prechistenskaya naberezhnaya, Moscow, 119034, Russian Federation; E-mail: sxzex@yandex.ru

\begin{abstract}
Implementation of the sustainable development goals (SDGs) is one of the key elements of the current international agenda. But some countries the least developed countries (LDCS), face serious difficulties in doing so. Such states have extremely limited internal resources and cannot ensure their own development; as such, they require the involvement of more developed states. Therefore, a key factor to ensure sustainable development is the facilitation and widening of trade and investment cooperation with partners that can provide financing support for the most urgent investment gaps, demand for export products, and imports of necessary goods and services. Traditional collaboration models with partners from developed countries cannot fully meet the needs of the LDCs in the current international context. This situation provides windows of opportunity as new power centres pursue their economic and political goals. China $(P R C)$ has a special place among these emerging powers.

This article analyses the economic cooperation of China with its 10 key trade partners among the LDCs (LDCs-10). The author suggests various rationales for the PRC's cooperation with the LDCs, examines the importance of this cooperation for achieving the SDGs, and presents an applied methodology. The first part of the article covers the particularities and general assessment of China's development finance. The author then analyses the main aspects of China's trade policy and its trade and economic cooperation with the LDCs-10. In conclusion, the author considers the dynamics of the key indicators of socio-economic and political development of the PRC and the LDCs-10 and evaluates the relative effectiveness and efficiency of their cooperation through the prism of the SDGs' implementation.
\end{abstract}

Key words: sustainable development goals; SDGs; sustainable development; the PRC; China; foreign policy; trade policy; foreign investment; the 2030 Agenda for Sustainable Development

For citation: Mikhnevich S. (2020) Pursuing Balance: Analysis of the PRC's Implementation of Trade and Investment SDGs in Cooperation With Leading Partners From the Least Developed Countries. International Organisations Research Journal, vol. 15, no 1, pp. 84-119 (in English). DOI: 10.17323/1996-7845-2020-01-04.

${ }^{1}$ The editorial board received the article in August 2019.

${ }^{2}$ The study was carried out as part of the research work of the state task of the RANEPA "Analysis of the contribution of the G20 countries to the implementation of trade and investment areas in the framework of the Sustainable Development Goals" (2020). 


\section{Introduction}

The comprehensive implementation of the 2030 Agenda for Sustainable Development (hereinafter, the 2030 Agenda) is a very complicated and nontrivial task which requires the active involvement of the international community as a whole. As noted in the 2030 Agenda, "sustainable development recognizes that eradicating poverty in all its forms and dimensions, combating inequality within and among countries, preserving the planet, creating sustained, inclusive and sustainable economic growth and fostering social inclusion are linked to each other and are interdependent" [UN, 2015]. M. Larionova and E. Safonkina argue that "the United Nations (UN) sustainable development goals (SDGs) established in the 2030 Agenda for Sustainable Development adopted in 2015 collectively serve as a universal guide for developed and developing countries in their national policies and international cooperation aimed at meeting global challenges" [Larionova, Safonkina, 2018]. The SDGs include 17 goals and 169 tasks which are "integrated and indivisible and balance the three dimensions of sustainable development: the economic, social and environmental” [UN, 2015].

It is not a secret that the most serious difficulties in the implementation of the SDGs are experienced by the least developed countries (LDCs). This descriptor was introduced by the UN General Assembly in 1971 to identify countries in urgent need of international support for socio-economic development. The LDC classification has been updated many times since then. The list of LDCs is reviewed every three years by the Committee for Development Policy, a group of independent experts that reports to the Economic and Social Council of the UN. The current list (reviewed in December 2018) includes 47 countries [Ibid., n. d., a]. Only five countries have ever graduated from LDC status: Botswana in December 1994, Cabo Verde in December 2007, Maldives in January 2011, Samoa in January 2014 and Equatorial Guinea in June 2017 [UNCTAD, 2019a].

There are many reasons for the negative situation experienced by these states, such as the deformed structure of national economies dominated by low productivity sectors and poor diversification, wide investment gaps, high inequality, poor human capital, high corruption, and many other severe problems. In Africa alone, within a period of 40 years (1970-2010) \$854 billion was withdrawn as the proceeds of corruption or unpaid taxes and duties [Safronova, 2019, p. 98]. Features of the socio-economic development in LDCs are discussed by A.S. Pankova and S.V. Mikhnevich [2018]. It is safe to say that due to the extreme limitations of LDC capacities, a major means to enhance their domestic situation and make progress toward implementation of SDGs is the development of cooperation with external powers such as the People's Republic of China (PRC).

For China, constructive investment activities and trade have been the most important factors behind the exponential growth and crucial changes in the Chinese economy since the beginning of the policy of "reform and opening" in the late 1970s. Significantly, while China has been solving domestic issues it has also actively supported the development of foreign partners. Mao Zedong in 1971 emphasized that "African friends had brought China to the UN" [Safronova, 2019, p. 134].

China and the LDCs actively collaborate in various bilateral and multilateral fora, starting with the Non-Aligned Movement and the Group of 77 and China, and ending with the Group of 20 (G20) and the BRICS group of Brazil, Russia, India, China and South Africa. In the enumeration of existing mechanisms of forum diplomacy, south-south (among developing countries) and north-south (between developed and developing countries) cooperation fora are worth mentioning. South-south cooperation provides China with opportunities to gain the support of the developing world for Chinese initiatives and ideas, and to promote them 
in north-south dialogue on the global stage. SDG implementation, in addition to its socioeconomic value, is a major factor for China to increase its international influence and provide a positive environment for its own legitimate global leadership. The rationale behind China's bid for leadership is pragmatic: if it is not a leader, China risks losing capacities and resources for sustainable development and falling into a serious crisis.

The nature of the PRC's foreign policy under Xi Jinping's leadership has become more leadership-oriented and assertive. This also is evidenced in the launch of different initiatives and ideological concepts such as the Belt and Road Initiative (BRI) and the Community of Common Destiny (CCD) or Chinese dream. The BRI is aimed at the implementation of practical projects, while the CCD has as its goal the renewal of the international system on the basis of values. Thus, another important direction of Chinese foreign policy is to raise the potential of "international discourse power" (guoji huayuquan) through the publication of white papers, speeches by state leaders, international propaganda, and scientific and cultural exchanges [Denisov, Adamova, 2017, p. 76]. China traditionally declares that its foreign policy has as its core the concept of mutually beneficial cooperation and non-interference in domestic affairs. This approach increases the appeal of cooperation with China for many developing states that would otherwise have to conform to the conditions of partners from developed countries. China can maximize its own benefits from cooperation thanks to this mutuality.

The basic document of the PRC's policy on the SDGs is China's Position Paper on the Implementation of the 2030 Agenda for Sustainable Development. It argues that despite the significant and positive results from international cooperation, the world faces serious challenges which cannot be overcome by countries separately, noting that "all countries should work together to translate leaders' commitments to concrete actions by implementing the 2030 Agenda" [Ministry of Foreign Affairs of the People's Republic of China, 2016]. Table 1 shows the main approaches to SDG implementation that are presented in the paper.

Table 1. Main Elements of China's Position Paper on the Implementation of the 2030 Agenda for Sustainable Development

\begin{tabular}{|l|l|l|}
\hline \multicolumn{1}{|c|}{ General Principles } & \multicolumn{1}{|c|}{ Key Areas and Priorities } & \multicolumn{1}{c|}{ Means of Implementation } \\
\hline Peaceful development & Eradicate poverty and hunger & Strengthen capacity building \\
\hline Win-win cooperation & Maintain economic growth & $\begin{array}{l}\text { Create an enabling international } \\
\text { environment for development }\end{array}$ \\
\hline Integration and coordination & Advance industrialization & Strengthen development partnership \\
\hline Inclusiveness and openness & $\begin{array}{l}\text { Improve social security and social } \\
\text { services }\end{array}$ & Promote coordination mechanism \\
\cline { 1 - 2 } Sovereignty and voluntary action & Safeguard equity and justice & \multirow{2}{*}{ Improve follow-up and review } \\
\hline Common but differentiated & Protect the environment & \\
\hline \multirow{2}{*}{ responsibilities } & Address climate change & \\
\cline { 2 - 2 } & Efficiently utilize resources & \\
\cline { 2 - 3 } & Improve national governance & \\
\hline
\end{tabular}

Source: Compiled by the author on the basis of Ministry of Foreign Affairs of the People's Republic of China [2016]. 
This paper analyzes the performance of the PRC's policy on the fulfilment of SDG trade and investment tasks in cooperation with key LDC partners. The main research question is to find out if the PRC's development of economic cooperation with the LDCs leads to complex enhancement of the situation in the interests of the PRC and the LDCs.

The central hypothesis is that the PRC's strategy to implement trade and investment SDG targets is based on the pursuit of a complex political-economic good. This includes providing favourable conditions for the development of China and its key partners and maximizing the PRC's international influence. Fulfilling this strategy, China seeks to optimize the use of resources by taking economically viable decisions for political tasks. However, this sometimes results in deteriorating socio-economic and political situations in the partner countries.

The chronology of the research mainly covers the period 2015 to 2017, representing the first three years after the approval of the 2030 Agenda, due to the availability of socio-economic and political development indicators during this period.

In order to answer the research question, it is necessary to: analyze the main approaches and mechanisms of the PRC's development finance and outward investments; examine trade policies in China's relationships with the LDCs; identify China's key partners among the LDCs; determine actual trends in China's economic cooperation with its key LDC partners; and assess the dynamics of the main indicators of the socio-economic development.

A special methodology is deployed based on theoretical approach utilized by the research team at the Center for International Institutions Research at the Russian Presidential Academy of National Economy and Public Administration (RANEPA) for the "Analysis of the G20 Countries' Contribution to Implementation of the Trade and Investment Tasks of the Sustainable Development Goals (SDGs)" research project.

Among the targets outlined in the SDGs for which the completion of trade and investment cooperation plays the most important role due to their influence on the socio-economic development of the LDCs, four targets and their indicators have been selected:

- SDG 2 (End hunger, achieve food security and improved nutrition and promote sustainable agriculture); Target 2.b (Correct and prevent trade restrictions and distortions in world agricultural markets, including through the parallel elimination of all forms of agricultural export subsidies and all export measures with equivalent effect, in accordance with the mandate of the Doha Development Round); Indicator 2.b.2 (Agricultural export subsidies).

- SDG 10 (Reduce inequality within and among countries); Target 10.a (Implement the principle of special and differential treatment for developing countries, in particular, least developed countries, in accordance with World Trade Organization (WTO) agreements); Indicator 10.a.1 (Proportion of tariff lines applied to imports from least developed countries and developing countries with zero-tariff).

- SDG 17 (Strengthen the means of implementation and revitalize the global partnership for sustainable development); Target 17.10 (Promote a universal, rules-based, open, non-discriminatory and equitable multilateral trading system under the WTO, including through the conclusion of negotiations under its Doha Development Agenda); Indicator 17.1 (Worldwide weighted tariff-average).

- SDG 17 (Strengthen the means of implementation and revitalize the global partnership for sustainable development); Target 17.12 (Realize timely implementation of duty-free and quota-free market access on a lasting basis for all least developed countries, consistent with WTO decisions, including by ensuring that preferential rules of origin applicable to imports from least developed countries are transparent and simple, and contribute to facilitating market access); Indicator 17.12.1 (Average tariffs faced by developing countries, least developed countries and small island developing States). 
The PRC's 10 largest trade partners among the LDCs (hereinafter, the LDCs-10) based on combined export and import volumes for three years (2015, 2016 and 2017) were identified based on UN Conference of Trade and Development (UNCTAD) Stat data. Trade between the PRC and the LDCs-10 during the specified period was analyzed to identify the five largest export product groups for each country, define their share in the total export volume of each country to the world market and China, and calculate the ratio between export of the appropriate country and the LDCs-10 to China and their export to the world market. This analysis allows for an evaluation of the importance of China as an export partner for the LDCs-10. LDCs10 imports from China were also analyzed to identify the five key product groups of the PRC's exports to the LDCs-10 and to calculate the ratio between the appropriate exports of the PRC to the LDCs-10 and its exports to the world market. Further, the five largest product groups of Chinese exports to the world market were identified and the ratio between the PRC's appropriate export to the LDCs-10 and its export to the world market was calculated. This allowed an evaluation of the importance of the LDCs-10 as an export partner for China.

The impact of China's trade policy on the implementation of trade and investment SDG targets in the appropriate countries was assessed, including number of protectionist and liberalizing measures (direct and indirect) that were introduced. The assessment was made based on the following indicators: fluctuations in the bilateral trade of each LDCs-10 country with the PRC (year to year comparison) and fluctuations in the trade of each LDCs-10 country with the world (year to year comparison).

Finally, the dynamics of some indicators of socio-economic development in the LDCs-10 countries and China in 2015-18 were considered to assess the possible influence of cooperation between LDCs-10 countries and China on that indicator. The indicators are the following: gross domestic product (GDP) per capita (World Bank data), the Human Development Index (United Nations Development Programme (UNDP) data), the Global Competitiveness Index (World Economic Forum (WEF) data), gross capital formation (World Bank data), unemployment (World Bank data), the Corruption Perception Index (Transparency International data), and the Democracy Index (The Economist Intelligence Unit data).

It is important to note that, taking into account the influence on the socio-economic development of many factors behind the relationship between China and the LDCs, it is impossible to determine the particular level of influence of direct and indirect trade investment measures on the dynamics of socio-economic development indicators. For example, a decrease in the PRC's growth rates affects commodities markets, causing a fall in prices and a worsening economic situation in many LDCs due to their undiversified and undeveloped economic structures.

\section{Development Finance and Investment Cooperation}

Since 2014 PRC authorities have not published white papers on China's foreign aid. According to information revealed in February 2017, Xi Jinping, in his speech at the meeting of the Leading Small Group for Comprehensively Deepening Reforms, mentioned that the total amount of China's foreign aid in 1949-2016 exceeded RMB 600 billion ( $\$ 89.6$ billion) [RFA, 2017]. If development finance provided before 2012, RMB 345.63 billion ( $\$ 51.6$ billion) [Information Office of the State Council, the People's Republic of China, 2011, 2014], is deducted, China provided foreign aid in the amount of RMB 255 billion ( $\$ 38$ billion) in 2013-16.

Nevertheless, this information does not fully align with other data on China's foreign development assistance (FDA). In particular, in March 2017 the Xinhua agency, with reference to the ministry of finance of the PRC, provided data on China's foreign aid in 2012-16 [Ren, 
Zhou, 2017] according to which the total amount for the period reached RMB 92.3 billion ( $\$ 13.8$ billion). Excluding data for 2012, the total volume of China's FDA in 2013-16 was RMB 75.6 billion ( $\$ 11.3$ billion), including RMB 19.4 billion ( $\$ 2.9$ billion) in 2015 and RMB 20.6 billion ( $\$ 3.1$ billion) in 2016. The inconsistency of data on China's FDA impedes the analysis.

The key stakeholders in China's development finance and fulfilment of investment projects abroad are the Export-Import Bank of China (CEIB) and the China Development Bank (CDB). They "provide an intermediation function between financial markets and recipient countries based on a mechanism of sovereign guaranteed repayment of loans and market access for Chinese companies" [Zheng, 2016]. The banks review proposed projects for bankability and feasibility, risks, and payment capacity, and then decide on whether to provide finance. The legal bases of disbursements are agreements between the state bodies of the recipient countries and are independent of other Chinese ministries China International Development Cooperation Agency, which succeeded the Ministry of Commerce in this capacity [Zhou, Zhang, 2018].

It should not be forgotten that the banks evaluate forthcoming investments from the point of view of China's interests, which do not always align with the national interests of its investment partners. Rather low quality of governance in China's partners from the LDCs has frequently caused irrational costs and made it impossible for them to meet their obligations to China. As a result, titles to many projects and investment objects have been transferred to Chinese economic operators, inducing public dissatisfaction. Many developed countries competing with the PRC for influence in emerging markets accuse China of drawing its partners into a "debt trap" [Challaney, 2017]. Many observers point to the Hambantota Port of Sri Lanka, which was leased to China Merchant Port Holdings Limited (CM Port) for 99 years for $\$ 1.12$ billion in 2017 due Sri Lanka's incapacity to serve China's loans, as a vivid example of China's "debt diplomacy." Nevertheless, some experts think that "the real picture of Sri Lanka's debt crisis is very different and far more destructive. Debt owed to China is in fact the tip of the iceberg, and that should make the debt crisis all the more alarming. The Hambantota port deal is not merely an issue of Chinese debt - Sri Lanka has much larger economic issues that go well beyond the debt owed to China" [Moramudali, 2019]. Improper assessment of possible implications of China's finance and overestimation of its own capacities by Sri Lanka's authorities aggravated the situation.

The tight nature of China's foreign aid means that the vast majority of the projects are implemented by Chinese companies. Such an approach also limits possible benefits for the PRC's partners. "To some extent, Chinese aid patterns share some similarities with Japan's aid model, which is noticeably distant from the orthodox ODA model" [Zheng, 2016], and uses foreign aid to improve the international competitiveness of Japanese companies and their presence in targeted markets. Thus, the Measures on the Management of Foreign Technical Assistance Projects (Art. 3) stipulates that "technical assistance projects are in general terms implemented by the Chinese side. If the recipient is willing to implement, the Chinese side can take into account the actual situation and decide through consultation with the recipient, and hand over the technical assistance project to the recipient side for implementation" [Ministry of Commerce of the People's Republic of China, 2015]. According to the Forum on ChinaAfrica Cooperation (FOCAC) Beijing Action Plan (2019-21) adopted on 4 September 2018 "China will support Chinese companies in participating in Africa's infrastructure development by way of investment-construction-operation or through other models, with focus on enhancing cooperation on energy, transport, information, telecommunications and cross-border water resources" [FOCAC, 2019, Para. 3.3.2]. As a result, Chinese companies absorb most of China's development assistance. The Chinese scholar Zheng Yu supposes that "Chinese companies, regardless of their ownership structure, can use aid schemes to advance their commercial interests, which may create unintended consequences on foreign policy objectives" [Zheng, 2016]. 
Financial resources provided by China for FDA mainly fall into three types: grants (aid gratis), interest-free loans and concessional loans [Information Office of the State Council..., 2011]. "Grants are mainly used to help recipient countries to build hospitals, schools and lowcost houses, and support well-digging or water-supply projects, and other medium and small projects for social welfare. In addition, grants are used in projects in the fields of human resources development cooperation, technical cooperation, assistance in kind and emergency humanitarian aid" [Ibid.]. China hardly ever provides FDA in the form of cash. The grants are the nominal amounts of funds allocated for project implementation. A vivid example of a project fulfilled with the PRC's $\$ 8$ million grant is the construction of two schools in Juba (South Sudan) [All Africa, 2017].

"Interest-free loans are mainly used to help recipient countries to construct public facilities and launch projects to improve people's livelihood. The tenure of such loans is usually 20 years, including five years of use, five years of grace and ten years of repayment. Currently, interest-free loans are mainly provided to developing countries with relatively good economic conditions" [Information Office of the State Council..., 2011]. The operator of the interest-free loans is the CDB. The main difference between grants and interest-free loans is the requirement to repay the latter. By the end of 2018, the CDB has extended more than $\$ 50$ billion in funding to nearly 500 projects in 43 African countries [CDB, 2019].

China's \$30 million loan to Zambia in September 2018 [Solomon, 2018] is one example. The PRC successfully capitalized its influence there; Zambia has received financing from China many times. In 2017 the Zambian government forced the Zambia National Broadcasting Corporation (ZNBC) into a joint venture with the Chinese Start Times to form a company named TopStar Communications Limited. The new company will collect revenues for the next 25 years to service a $\$ 273$ million loan by China to digitalize ZNBC's operations. Start Times owns the majority $60 \%$ of TopStar Communications Limited, while ZNBC has a minority stake of $40 \%$ [Tumfweko, 2017].

One of the key mechanisms for delivering financing by the CDB is the China-Africa Development Fund (CADFund), through which the CDB has channelled about $\$ 23$ billion worth of investment to Africa [CDB, 2019]. China's financing influence is supported by the ChinaAfrica Inter Bank Association founded in September 2018 in the margin of FOCAC. The parties to the agreement are the CDB and 16 African banks. The main goal of the cooperation is to "enhance financial cooperation between all member banks to advance partnership in various domains such as China-Africa infrastructure interconnection, international cooperation and exchange in the humanities" [Business Insider, 2018].

"Concessional loans are mainly used to help recipient countries to undertake productive projects generating both economic and social benefits and large and medium-sized infrastructure projects, or to provide complete plant, mechanical and electrical products, technical services and other materials. Concessional loans are raised by the CEIB on the market, and since the loan interest is lower than the benchmark interest of the People's Bank of China, the difference is made up by the State as financial subsidies. The annual interest rate of China's concessional loans is between $2 \%$ and $3 \%$, and the period of repayment is usually 15 to 20 years (including five to seven years of grace)" [Information Office of the State Council, the People's Republic of China, 2011].

The distinctive feature of the concessional loans mechanism is an active application of the private-public partnership (PPP) targeted at accumulating significant sources for infrastructure projects. In PPP projects, Chinese finance covers the majority of project expenditures (around $85 \%)$. The remaining expenses are covered by the governments of the recipient countries [Mar- 
dashev, 2011]. Concessional loans of the CEIB do not fall into the categories of trade, investment, or aid, being part of the big investment deals.

One of the major examples of a concessional loan by China is the construction of the $756 \mathrm{~km}$ Ethiopia-Djibouti railway by China, completed in 2016. Construction of the Ethiopian section of the route cost around $\$ 3.4$ billion, $70 \%$ financed by the CEIB and $30 \%$ by the Ethiopian government [Railway Gazette International, 2016]. A consortium of the China Civil Engineering Construction Corporation (CCECC) and the China Railway Group (CRG) was assigned to carry out the operation and management of the railway [CCECC, 2016].

The launch of the BRI, in which 126 states and 29 international organizations take part, has significantly contributed to the expansion of the activities of the CDB and the CEIB [Mikhnevich, 2019]. Since the launch of the BRI, the CDB has issued loans for more than 600 projects in the Belt and Road (B\&R) countries, to a value surpassing $\$ 190$ billion. The CEIB provided finance for more than 1,800 projects (over $\$ 90$ billion) [Weizhen, 2019]. ${ }^{3}$

For project implementation, China also utilizes new institutions such as the $\$ 40$ billion Silk Road Fund (SRF) ${ }^{4}$ and the Asian Infrastructure Investment Bank (AIIB), whose registered capital is $\$ 100$ billion. Since the establishment of the SRF, contracted investment under the fund has reached $\$ 11$ billion, with actual investment adding up to $\$ 7.7$ billion [Office of the Leading Group for Promoting the Belt and Road Initiative, 2019]. As of the end of August 2019, the AIIB has signed 46 projects. The volume of the bank's investments in these projects amounted to $\$ 8.87$ billion. Ten projects came from India, the major beneficiary of the bank, followed by Indonesia and Bangladesh (five projects each) [AIIB, n. d.].

Taking into account that loans are frequently supplied by the investments of Chinese companies, the level of dependence of many developing countries, especially the LDCs, on Chinese financial sources will, in the mid- and long-term perspective, exceed the level of dependence on other foreign investors. For instance, in 2018 China was the second-largest investor in Africa behind the EU - greenfield FDI projects announced by China in 2018 reached $\$ 11.93$ billion, increasing from $\$ 8.7$ billion in 2017 [UNCTAD, 2019b, p. 35].

This is to a large extent related to increased Chinese activity under the FOCAC framework. At the 2015 FOCAC summit Xi Jinping announced 10 major plans to boost cooperation with Africa covering such areas as industrialization, agricultural modernization, infrastructure, financial services, green development, trade and investment facilitation, poverty reduction and public welfare, public health, people-to-people exchanges, and peace and security. To ensure smooth implementation of the initiatives, $\mathrm{Xi}$ announced that China would offer funding support in the amount of $\$ 60$ billion, including $\$ 5$ billion in free aid and interest-free loans, $\$ 35$ billion in preferential loans and export credit on more favourable terms, $\$ 5$ billion in additional capital for the China-Africa Development Fund and the Special Loan for the Development of African SMEs each, and a China-Africa production capacity cooperation fund with initial capital of $\$ 10$ billion [Xinhua News Agency, 2015].

At the 2018 FOCAC summit China undertook to:

- encourage Chinese companies to make investments worth at least $\$ 10$ billion in Africa

in the next three years;

- set up a $\$ 5$ billion special fund for financing imports from Africa;

- extend $\$ 20$ billion in credit lines,

- support the setting up of a $\$ 10$ billion special fund for development financing;

- extend $\$ 15$ billion in grants, interest-free loans and concessional loans to Africa.

\footnotetext{
${ }^{3}$ For more on BRI outcomes see S. Mikhnevich [2017, 2019].

${ }^{4}$ In 2017 the SRF capital was raised by RMB100 billion.
} 
For African LDCs, heavily indebted and poor countries, landlocked developing countries, and small island developing countries that have diplomatic relations with China, any debt they had incurred in the form of interest-free Chinese government loans due to mature by the end of 2018 would be exempted [FOCAC, 2019].

Simultaneously, PRC authorities introduced some measures aimed at systematization of outbound FDI and prevention of severe capital flight. According to Forbes, in 2008-17 "an estimated $\$ 3.8$ trillion in capital has left China. Net FDI over the same period of time has amounted to $\$ 1.3$ trillion, leaving the country with a net loss" [Gunter, 2017]. A significant amount of the withdrawn resources was disguised as FDI.

To improve the situation, the National Development and Reform Commission (NDRC) together with three state bodies issued Opinions on Further Guiding and Regulating Outbound Investment No 74 in August 2017, promulgated then by the state council. The document classified outbound investment into three groups depending on the sector and recipient country: encouraged, restricted, and prohibited transactions [Office of the State Council of the People's Republic of China, 2017]. In December 2017 the NDRC issued Administrative Measures for Enterprise Outbound Investment No 11 [NDRC, 2017]. According to the document, monitoring of outward investments would no longer be limited to pre-transaction verification and record-filing, but also would cover the periods during and after transactions. The Administrative Measures categorized outbound investments into two types: those conducted directly by domestic investors and those conducted through overseas enterprises controlled by domestic investors [Wang, Huang, Tang, 2018]. Subsequently, in 2018 Chinese authorities adopted Management Provisions for Outward Investment by Enterprises and the Interim Measures for Reporting on the Registration (Approval) of Outward Investment [NDRC, 2019].

Table 2. Requirements for Verification/Record-Filing of Outbound FDI in the PRC Under Administrative Measures for Enterprise Outbound Investment No 11

\begin{tabular}{|l|l|l|l|}
\hline Type of Investment & $\begin{array}{l}\text { Amount of Investment } \\
\text { by Chinese Party }\end{array}$ & $\begin{array}{l}\text { Outbound Investments } \\
\text { Conducted Directly } \\
\text { by Domestic Investors }\end{array}$ & $\begin{array}{l}\text { Outbound Investments } \\
\text { Conducted by Domestic } \\
\text { Investors Through } \\
\text { Controlled Overseas } \\
\text { Enterprises }\end{array}$ \\
\hline Sensitive Sector & Any amount & Verification by NDRC & Verification by NDRC \\
\hline Non-Sensitive Sector & $\geqslant 300$ million & Record-filing at NDRC & $\begin{array}{l}\text { Situation report for non- } \\
\text { sensitive projects with } \\
\text { large amount an NDRC }\end{array}$ \\
\cline { 2 - 4 } & $\leqslant \$ 300$ million & $\begin{array}{l}\text { Centrally managed state- } \\
\text { owned enterprises: } \\
\text { record-filing at NDRC } \\
\text { fication, record-filing or } \\
\text { report required }\end{array}$ & $\begin{array}{l}\text { No pre-transaction veri- } \\
\text { ficat enterprises: } \\
\text { record-filing at the pro- } \\
\text { vincial level NDRC }\end{array}$ \\
\hline
\end{tabular}

Source: Based on NDRC [2017].

FDI policy regulations are under constant development. That should support restoration of the PRC's leading position as an international investor: in 2016-18, due to strengthening control Chinese outbound FDI had fallen from $\$ 196$ billion to $\$ 130$ billion per year 
[UNCTAD, 2018, 2019]. First estimations of Chinese outbound FDI in 2019 do not show positive trends: in 2019 Chinese outbound FDI declined 6\% to RMB 807.95 billion ( $\$ 118$ billion) [Reuters, 2020].

Another serious problem is "hidden investment" by the PRC. According to S. Horn, C. Reinhart and C. Trebesch [2019] about one half of China's overseas loans to the developing world are hidden. As of 2018, the government of China held debt of more than $\$ 5$ trillion owed by the rest of the world (6\% of world GDP), up from less than $\$ 500$ billion in the early 2000s (1\% of world GDP). If added to foreign equity and direct investments (not shown), China's total financial claims abroad amounted to more than $8 \%$ of world GDP (nearly \$6.7 trillion) in 2017 [Horn, Reinhart, Trebesch, 2019, p. 5]. Horn, Reinhart and Trebesch note that "today's debt levels in the developing world look dangerously close to their level in 1981, just before the so-called 'Third World Debt Crisis' broke out. This is particularly true once we add 'hidden" Chinese debts' [Ibid., p. 30]. Non-transparency of many developing countries' international obligations to China, their biggest debt holder, significantly impedes decision-making to prevent possible crisis.

The position of China in the partner-states is being strengthened by the "third-party market cooperation" model (TPMC). Applying this model, Chinese enterprises and their counterparts in developed countries can jointly implement projects in third countries. According to Loletta Chow, global leader of EY China Overseas Investment Network and B\&R Task Force leader, TPMC "is able to connect China's competitive production capacity and developed countries' advanced technology with the third-party's vast development demand" [Chen, 2019]. According to French Ambassador to China Jean-Maurice Ripert, China and France are discussing 13 projects for development under the TPMC. Besides France, China has also signed TPMC documents with Japan, Spain, the Netherlands, Belgium and Australia, as well as with some international organizations [Cao, 2019].

A special direction of Chinese FDA is the establishment of economic and trade cooperation zones. By September 2018, China had established 113 such zones in 46 countries, while Chinese businesses had invested more than $\$ 36.6$ billion. The 4,663 companies working there generate about $\$ 3.1$ billion in tax revenue and created approximately 287,000 jobs in the host countries [EY, 2018, p. 5].

\section{Trade policy}

China applies an active trade policy, reasonably considering it to be a very important instrument of national economic development, especially in conditions of severe economic war with the U.S. In this regard, China is working to gradually switch the existing model of export-oriented development to one driven by domestic demand. It implies, on the one hand, the extension of imports, and support for the competitiveness of national enterprises, on the other.

In the context of reaching indicator 2.b.2 Agricultural export subsidies and changes to the tariffs for agricultural export and import to/from the developing countries and the LDCs, such an approach leads to interesting and ambiguous political decisions. While the total volume of global export subsidies (applied by WTO members) has fallen (from $\$ 3.8$ billion in 2003 to $\$ 117$ million in 2016) [UN, n. d., b], the overall amount of support for agricultural producers is far from decreasing. Agricultural support for producers in the PRC in 2015-18 was approximately $\$ 200$ billion a year, compared to $\$ 26$ billion in 2003 [OECD, n. d.].

In the years since the PRC's accession to the WTO, China's average import tariff has decreased from $15.3 \%$ in 2001 to $7.5 \%$ in 2019 [Aleksandrova, 2018, p. 275; Li, 2019]. As rightly pointed out by M. Alexandrova, the "result had been achieved mainly through bilateral trade 
agreements signed by China" [Aleksandrova, 2018]. Today China is the party to 15 such agreements. ${ }^{5}$

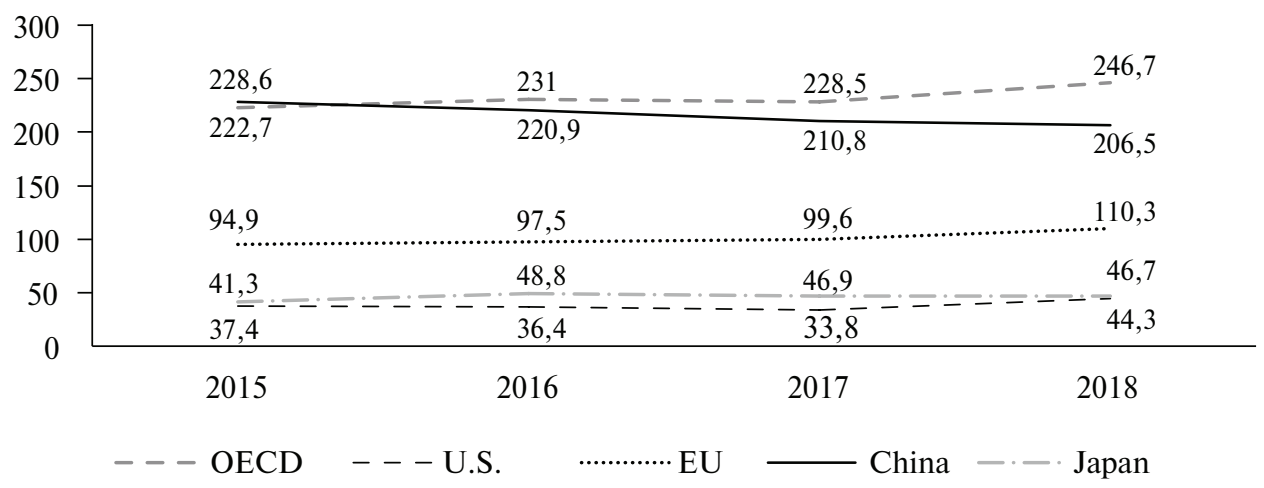

Fig. 1. Agricultural Producer Support, \$ billion

Source: [OECD, n. d.].

China's movement toward decreased tariffs under existing foreign trade agreements (FTAs) is consistent with current international trends: the improvement of terms and conditions under signed agreements and those being established creates new trade barriers for outsiders. Taking this into account, China is facilitating negotiations on the Regional Comprehensive Economic Partnership (RCEP). As a result, members of the new agreement will create a new type of FTA, covering not only tariff issues but also non-tariff barriers, intellectual property, digital commerce, investments, and standards.

The internationalization of technical standards is very important to China. For this purpose, China is utilizing its international initiatives such as the BRI (via the Action Plan on Belt and Road Standard Connectivity) and introducing new ideological concepts such as institutional openness (IO). IO should replace openness through the movement of goods and production factors. It "assumes 'soft forms of connectivity' with common rules, standards, certification procedures, and intellectual property rights" [Zhao, 2019, p. 29]. Thus, promoting the IO concept, China builds capacity for gaining influence in spheres where it most often had to abide by the rules and standards stipulated by other actors.

China has three main types of import tariff regulations [Aleksandrova, 2018]. The first is the general trade regime for WTO non-members which imposes the maximum import tariff rates. The second is the most-favoured-nation (MFN) regime applied to WTO members and countries that have signed agreements with China on MFN maintenance. It assumes reduced import tariff rates and covers $99 \%$ of trade items (namely, 8,549) [Ministry of Finance of the People's Republic of China, 2018].

The third is preferential tariffs (PT), which are lower than the MFN tariffs. They apply to imports from some countries, and to some trade items irrespective of the exporting country. The number of trade items subject to interim preferential import tariff rates was reduced from 948 to 706 in 2019 [Ibid., 2017; 2018].

The PRC's average import tariff rates in contrast to the EU and the U.S. do not demonstrate constant reduction; this is similar to the Japanese approach, in which there has been an

\footnotetext{
${ }^{5}$ Author's calculations based on WTO [n. d., a].
} 
increase in rates after a slight decline. But unlike with Japan, the PRC's average import tariff rate from $2015-17$ decreased by $0.7 \%$, and has not grown.

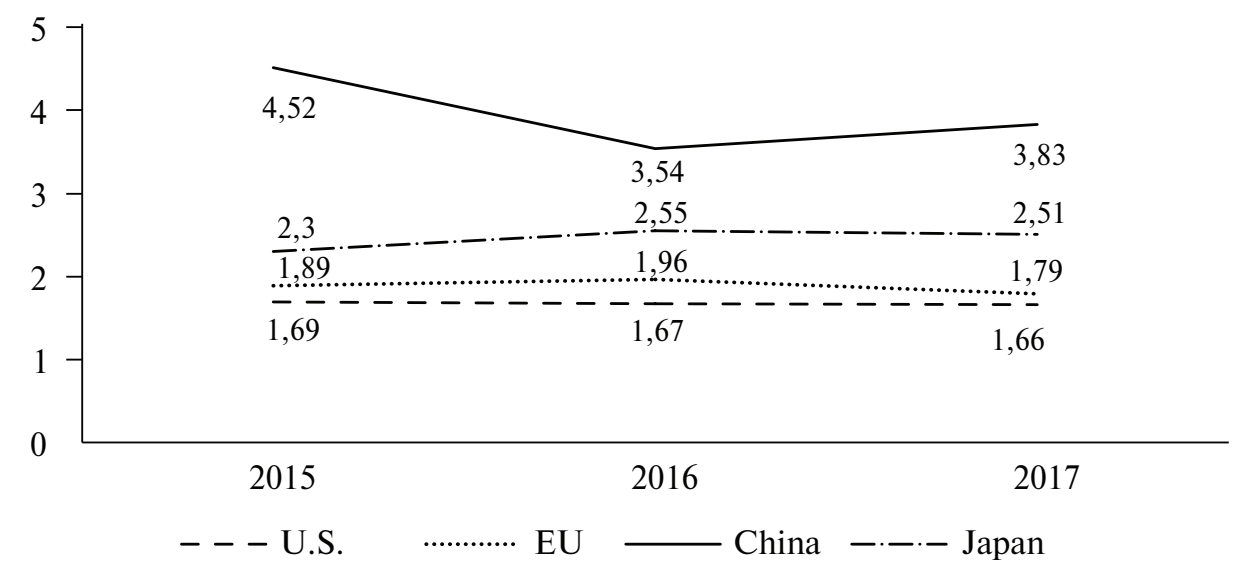

Fig. 2. Average Import Tariff Rates, $\%$

Source: [World Bank, n. d., d].

The dynamics of average tariff rates applied by China under the MFN and PT regimes are unsustainable. The decrease in rates of most tariff lines in 2016 gave way to growth in 2017 that, to some extent, exerted pressure on China's imports of appropriate products. Nevertheless, within three years, rates of all tariff lines had been reduced.

Table 3. Average Tariff Applied by the PRC Under MFN and PT Regimes by Type of Product, \%

\begin{tabular}{|l|l|l|l|}
\hline \multicolumn{1}{|c|}{ Type of Product } & \multicolumn{1}{c|}{$\mathbf{2 0 1 5}$, MFN/PT } & \multicolumn{1}{c|}{$\mathbf{2 0 1 6 , \text { MFN/PT }}$} & \multicolumn{1}{c|}{ 2017, MFN/PT } \\
\hline Agricultural products & $11.49452 / 9.24926$ & $12.0711 / 9.20954$ & $11.95115 / 9.01074$ \\
\hline Arms & $13.00884 / 12.73241$ & $13.04521 / 11.03205$ & $13 / 12.39568$ \\
\hline Industrial products & $7.91048 / 5.38717$ & $3.74072 / 2.88221$ & $4.41724 / 3.62125$ \\
\hline Oil & $0 / 0$ & $0 / 0$ & $0 / 0$ \\
\hline Clothing & $16.04429 / 9.9698$ & $16.16864 / 7.71158$ & $16.05713 / 9.0394$ \\
\hline Textiles & $7.72047 / 5.26113$ & $7.58446 / 4.59315$ & $7.83193 / 5.04397$ \\
\hline All products & $7.47456 / 5.19257$ & $4.06539 / 3.09468$ & $4.58926 / 3.67714$ \\
\hline
\end{tabular}

Source: [UN, n. d., b].

Today the lowest import tariffs are applied by the PRC to countries that are major exporters of commodities to China. Only eight tariff groups are subject to China's import quotas: wheat, maize, rice, sugar, wool, woollen clothing, cotton and chemical fertilizers [Ministry of Finance of the People's Republic of China, 2018].

China's partners from the LDCs and low-income developing countries enjoy the most favourable tariff treatment. This approach contributes to the positive dynamics of indicator 17.12.1 - Average tariffs faced by developing countries, LDCs and small island developing States, and facilitates duty-free and quota-free access by the LDCs to China's market. On 1 April 2017, 
the new Administrative Measures of the PRC Customs on Rules of Origin of Imported Goods from the LDCs Entitled to Special Preferential Tariff Treatment (the General Administration of Customs of the PRC Decree No 231) entered into force. The new Decree made exporting goods to China easier for the LDCs by expanding the criteria determining the national source of a product and streamlining the consignment process. The list of the beneficiaries was extended to 41 LDCs (31 in Africa and 10 in Asia) [UN, n. d., c]. To support the LDCs in implementing the 2014 WTO Trade Facilitation Agreement (which was fully implemented by the PRC) [WTO, n. d., b], China donated \$1 billion [Ibid., 2018].

China is gradually extending duty-free treatment to a significant share of imports from the LCDs and developing countries (Table 3). In 2017 the proportion of tariff lines applied by China to imports from the LDCs and developing countries with zero-tariff reached $36.68805 \%$ (34.60758\% in 2015) [UN, n. d., b]. However, the fact that many developed countries outstrip China on this indicator should be a subject of attention for Chinese authorities. At the same time, duty-free quota-free treatment (the DFQF scheme) for LDCs granted by China has covered $96.6 \%$ of tariff lines (93.5\% of tariff lines for agricultural products, $97.1 \%$ for others) [Ibid., n. d., d]. The DFQF scheme is available to all LDCs that have diplomatic relations with China [Ibid., n. d., e].

Table 4. Proportion of Tariff Lines Applied by the PRC to Imports From the LCDs and Developing Countries With Zero-Tariff, \%

\begin{tabular}{|l|c|c|c|}
\hline \multicolumn{1}{|c|}{ Type of Product } & $\mathbf{2 0 1 5}$ & $\mathbf{2 0 1 6}$ & $\mathbf{2 0 1 7}$ \\
\hline Agricultural products & 34.14461 & 33.69783 & 35.90482 \\
\hline Arms & 27.73109 & 29.03981 & 31.52174 \\
\hline Industrial products & 37.25147 & 37.64189 & 39.14997 \\
\hline Oil & 62.5 & 57.89474 & 68.96552 \\
\hline Clothing & 15.33568 & 15.29873 & 20.15559 \\
\hline Textiles & 25.14476 & 25.81373 & 27.45283 \\
\hline All products & 34.60758 & 34.90806 & 36.68805 \\
\hline
\end{tabular}

Source: [UN, n. d., b].

The PRC's weighted applied duty on imports from the LCDs in 2017 has been $0.8 \%$, including $14.5 \%$ for agricultural products (making up $64.4 \%$ of China's agricultural imports from the LCDs) and $0.2 \%$ for other products (98.5\% of China's other imports from the LCDs) [WTO, 2019].

Analysis of the PRC's trade with the LCDs shows that the LDCs-10 list consists of six African countries (Angola, Democratic Republic of the Congo, Ethiopia, Sudan, Tanzania and Zambia), three countries from the Asia-Pacific (Democratic People's Republic of Korea, Cambodia and Myanmar) and one South Asian country (Bangladesh). Angola is the largest LDCs-10 exporter to China (with $48.65 \%$ of the LDCs-10 combined export volume) while Bangladesh is the largest importer of Chinese products among the members of the group (29.68\% of the PRC's exports to the LDCs-10).

In 2015-17 China's exports to the LDCs-10 was 1.4 times higher than Chinese imports from these countries. In this period, the exports and imports of the LCDs to China demonstrated similar dynamics: a slight decrease in 2016 and return to growth in 2017. But while LDCs-10 exports in 2017 significantly surpassed the volumes of 2015, imports did not reach 2015 levels. 
Table 5. China's 10 Largest Trade Partners Among the LCDs and Low-Income Countries (LDCs-10)

\begin{tabular}{|c|c|c|c|c|c|c|c|c|c|c|}
\hline \multicolumn{5}{|c|}{ Exports to the PRC, $\$$ billion } & \multicolumn{5}{|c|}{ Imports From the PRC, $\$$ billion } & \multirow{3}{*}{ 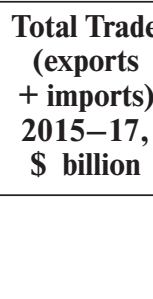 } \\
\hline Year & \multirow[t]{2}{*}{2015} & \multirow[t]{2}{*}{2016} & \multirow[t]{2}{*}{2017} & \multirow[t]{2}{*}{ Total } & Year & \multirow[t]{2}{*}{2015} & \multirow[t]{2}{*}{2016} & \multirow[t]{2}{*}{2017} & \multirow[t]{2}{*}{ Total } & \\
\hline Country & & & & & Country & & & & & \\
\hline Angola & 14.28 & 12.78 & 15.4 & 42.46 & Angola & 4.01 & 1.75 & 2.28 & 8.04 & 50.5 \\
\hline Bangladesh & 0.76 & 0.88 & 0.86 & 2.5 & Bangladesh & 11.67 & 11.8 & 12.45 & 35.92 & 38.42 \\
\hline Myanmar & 4.68 & 4.61 & 5.34 & 14.63 & Myanmar & 6.43 & 5.4 & 6.12 & 17.95 & 32.58 \\
\hline DPRK & 3.31 & 2.54 & 1.53 & 7.38 & DPRK & 4.01 & 3.49 & 3.71 & 11.21 & 18.59 \\
\hline Ethiopia & 0.28 & 0.33 & 0.34 & 0.95 & Ethiopia & 5.61 & 5.21 & 5.06 & 15.88 & 16.83 \\
\hline Cambodia & 0.4 & 0.53 & 0.75 & 1.68 & Cambodia & 3.27 & 3.95 & 4.37 & 11.59 & 13.27 \\
\hline $\begin{array}{l}\text { Dem. Rep. } \\
\text { of the Congo }\end{array}$ & 2.28 & 2.19 & 3.33 & 7.8 & $\begin{array}{l}\text { Dem. Rep. } \\
\text { of the } \\
\text { Congo }\end{array}$ & 1.47 & 1.15 & 1.05 & 3.67 & 11.47 \\
\hline Sudan & 1.13 & 1.38 & 1.68 & 4.19 & Sudan & 2.4 & 1.95 & 2.24 & 6.59 & 10.78 \\
\hline Tanzania & 0.39 & 0.3 & 0.19 & 0.88 & Tanzania & 2.52 & 2.71 & 2.62 & 7.85 & 8.73 \\
\hline Zambia & 1.38 & 1.23 & 2.29 & 4.9 & Zambia & 0.75 & 0.61 & 0.97 & 2.33 & 7.23 \\
\hline Total: & 28.89 & 26.77 & 31.71 & 87.27 & Total: & 42.14 & 38.02 & 40.87 & 121.03 & 208.3 \\
\hline
\end{tabular}

Source: Author's calculations based on UNCTAD [n. d.].

The total number of LDCs-10 countries' priority product groups in terms of exports to the world market (hereinafter, WPPG) reached 25 items (Annex 1). ${ }^{6}$ The LDCs-10 countries are competitors in $\mathbf{1 5}$ product groups on the global market (appropriate product groups are export priorities of two of the LDCs-10 countries, at least). Three product groups (articles of apparel \& clothing accessories; gold, non-monetary (excluding gold ores and concentrates); vegetables and fruits) are priorities for four LDCs-10 countries at once. Four product groups (fish, crustaceans, molluscs and preparations thereof; metalliferous ores and metal scrap; non-metallic mineral manufactures, n.e.s.; petroleum, petroleum products and related materials) are priority sectors for three of the LDCs-10 countries. Ten product groups are unique priorities for separate LDCs-10 countries and do not overlap with other each other. For Angola such special products are cork and wood; crude fertilizers other than division 56, and crude minerals; for Bangladesh - textiles fibres and their wastes; for Cambodia - road vehicles; for the Democratic Republic of the Congo - inorganic chemicals; for the DPRK - coal, coke and briquettes; iron and steel; for Myanmar - gas, natural and manufactured; for Sudan - live animals other than animals of division 03. Zambia, Tanzania and Ethiopia do not have priority product groups which do not coincide with other LDCs-10 countries' export priorities.

Not all WPPGs of the LDCs-10 countries are the priority product groups of the exports to China (hereinafter - CPPG). China did not import coffee, tea, cocoa, spices, and manufac-

${ }^{6}$ For each LDC-10 the five largest export products to the global market (WPPG) have been identified. These were combined to define the sectoral structure of the LDCs-10 countries' export priorities. 
tures thereof from Angola in 2015-17; nor inorganic chemicals from the Democratic Republic of the Congo in 2016-17; nor gold, non-monetary (excluding gold ores and concentrates) from Cambodia, Ethiopia or Sudan in 2015-17. China's imports of some WPPGs of LDCs-10 countries are statistically insignificant.

China's share in the exports of LDCs-10 countries' five largest WPPGs ${ }^{7}$ was $\mathbf{2 5 . 0 5 \%}$ (\$64.502 billion) of their total appropriate exports to the global market (\$257.504 billion) in 2015-17. From the five largest WPPGs, four sectors coincide with CPPGs. ${ }^{8}$

The share of the PRC in LDCs-10 countries' five largest CPPGs' exports was $\mathbf{2 6 . 9 6 \%}$ (\$67.477 billion) of their appropriate exports to the world market (\$250.186 billion) in 201517. Moreover, the ratio between petroleum, petroleum products and related materials exports from the LDCs-10 countries to China (the most important product group of LDCs-10 exports for China) and the LDCs-10 countries' exports of these products globally reached $\mathbf{4 6 . 6 4 \%}$ (\$44.992 billion) in 2015-17. The PRC's share in all 25 WPPGs' exports by LDCs-10 countries to the global market was $\mathbf{2 5 . 3 3 \%}$ (\$83.045 billion) of their total appropriate exports to the world market (\$327.858 billion).

The LDCs-10 countries' five largest WPPGs in 2015-17 accounted for $\mathbf{8 . 0 3 \%}$ (\$73.776 billion) $)^{9}$ of China's appropriate global imports in total (\$918.504 billion) or $9.27 \%$ of China's appropriate imports from all LDCs (\$796.13 billion).

As for the significance of LDCs-10 countries for China's exports, the share of these countries in the exports of the five largest WPPGs from China in 2015-17 was just 0.9\% (\$28.741 billion) of global exports worth \$3,191.385 billion. Interestingly, one of the WPPGs (articles of apparel \& clothing accessories) is a priority for China and the LDCs-10 countries as well. Exports by the LDCs-10 of articles of apparel \& clothing accessories to the global market in 2015-17 were worth $\$ 111.499$ billion (34\% of the LDCs-10 total exports of WPPGs), while the appropriate exports from the PRC reached $\$ 490.216$ billion (15.36\% of China's WPPGs exports). So, China and the LDCs-10 countries are competitors in this product group on the global market. Simultaneously, the significance of this WPPG's exports compared to those of other WPPGs is higher for the LDCs-10 than it is for China. The share of the LDCs-10 in China's global exports of the five largest priority product groups of China's exports to the LDCs-10 (hereinafter, $\mathrm{LPPG}^{10}$ ) is $\mathbf{2 . 5 9 \%}$ (LPPG exports to the LDCs-10 from China worth $\mathbf{\$ 6 1 . 0 0 9}$ billion against appropriate Chinese exports to the world market worth $\$ \mathbf{2 , 3 5 1 . 1 8 8}$ billion).

The PRC's trade policy regarding exports from the LDCs-10 countries to China is very active. In 2015-17 it included, at least, 141 liberalizing and 42 harmful interventions. It is important to note that many of these interventions were not targeted, but rather have had an indirect influence on LDCs-10 countries' exports. The largest number of liberalizing interventions has been implemented toward the exports of Angola and Sudan, while most of the harmful measures have affected Myanmar and Bangladesh. The product group covered by the most liberalizing and protectionist interventions is petroleum, petroleum products and related materials, with 44 and six interventions respectively.

\footnotetext{
${ }^{7}$ Articles of apparel \& clothing accessories; petroleum, petroleum products and related materials; nonferrous metals; gas, natural and manufactured; gold, non-monetary (excluding gold ores and concentrates).

${ }^{8}$ With the exception of gold, non-monetary (excluding gold ores and concentrates. The fifth CPPG is coal, coke and briquettes.

${ }^{9}$ The data vary due to differences in the data sources for UNCTAD Stat (national statistical services of the LDCs-10 and General Administration of Customs of the PRC).

${ }^{10}$ Textile yarn and related products; electrical machinery, apparatus and appliances, n.e.s.; telecommunication and sound recording apparatus; iron and steel; road vehicles.
} 
Table 6. The PRC's Trade Interventions and the Dynamics of China and LDCs-10 Trade in LDCs-10 WPPGs

\begin{tabular}{|l|c|c|c|c|c|c|c|}
\hline \multirow{2}{*}{ Country } & \multicolumn{2}{|c|}{$\begin{array}{c}\text { Number } \\
\text { of Interventions }\end{array}$} & \multicolumn{4}{c|}{ LDCs-10 Export Covered Interventions, } & $\begin{array}{c}\text { Average } \\
\text { Custom Tariff } \\
\text { Rate, \% }\end{array}$ \\
\cline { 2 - 7 } & $\begin{array}{c}\text { Libera- } \\
\text { lizing }\end{array}$ & Harmful & $\begin{array}{c}\text { Libera- } \\
\text { lizing and } \\
\text { Harmful }\end{array}$ & $\begin{array}{c}\text { Only } \\
\text { Harmful }\end{array}$ & $\begin{array}{c}\text { Only Libe- } \\
\text { ralizing }\end{array}$ & $\begin{array}{c}\text { Total Export } \\
\text { Covered by All } \\
\text { Types of } \\
\text { Measures }\end{array}$ & \\
\hline Angola & 23 & 4 & 42,434 & 0.001 & 0.004 & $42,434.005$ & 0.02 \\
\hline Bangladesh & 14 & 8 & 446.83 & 176.23 & 895.9 & $1,518.96$ & 2.79 \\
\hline Cambodia & 11 & 3 & 203.14 & 0 & 292.18 & 495.32 & 0.55 \\
\hline DPRK & 19 & 4 & 152.46 & $2,859.4$ & $3,243.83$ & $6,255.69$ & - \\
\hline $\begin{array}{l}\text { Dem. Rep. } \\
\text { of the Congo }\end{array}$ & 15 & 4 & 331.23 & $1,811.3$ & 2,695 & $4,837.53$ & 4.77 \\
\hline Ethiopia & 10 & 3 & 253.34 & 0 & 240.86 & 494.2 & 0.41 \\
\hline Myanmar & 14 & 10 & 6,328 & $1,715.78$ & $1,241.64$ & $9,285.42$ & 0.78 \\
\hline Sudan & 21 & 3 & 480.52 & 0.0008 & $1,039.5$ & $1,520.021$ & 6.92 \\
\hline Tanzania & 9 & 1 & 0 & 131.83 & 58.43 & 190.26 & 0.48 \\
\hline Zambia & 5 & 2 & 1,118 & 0.0008 & $1,247.54$ & $2,365.541$ & 0.72 \\
\hline Total & 141 & 42 & $51,747.52$ & $6,694.54$ & $10,954.88$ & $69,396.95$ & \\
\hline
\end{tabular}

Source: Author's calculations based on Global Trade Alert [n. d.] and UNCTAD [n. d., 2016].

The main volume of the liberalizing measures covers LDCs-10 commodity exports to China. In some cases, the interventions are implemented toward import products that are not the most important for China, or toward products which are not or almost not produced in the partner countries. At the same time, some sectors (for example, articles of apparel \& clothing accessories), being China's WPPGs or in need of additional support, are subject to direct or indirect harmful measures, irrespective of the products' complexity.

\section{Conclusion}

The results of the survey affirm the importance of China as an economic partner for many LDCs, in particular the LDCs-10 countries. China accounts for at least $25 \%$ of their exports in the WPPGs and other products as well. This highlights the dependence of the LDCs' economic growth and development on their trade with China. The situation with investments reaffirms China's significance - China is one of the largest investors in Myanmar, Cambodia and Bangladesh. In Myanmar, China is second to Singapore as the largest investor $(\$ 20.37$ billion in accumulated FDIs as of 31 January 2019, \$5.5 billion in investments in 2015-18, \$1.395 billion in investments in 2017-18) [DICA, n. d.]. In Cambodia and Bangladesh, China is the largest investor with $\$ 8.75$ billion (from 2016-August 2019) ${ }^{11}$ and $\$ 1.03$ billion (in 2018) [Bdnews24.com, 2019], respectively. The situation with China's investments in African LDCs-10 countries is similar.

${ }^{11}$ Author's calculations based on Council for the Development of Cambodia [n. d.] and Xinhua News Agency [2019]. 
The PRC's initiatives and practical decisions are very important factors promoting a favourable environment for the sustainable development of the LDCs. Against the background of declining activities by traditional donors and partners from developed countries, China's growing engagement raises the interest of the LDCs in enhancing partnership with the PRC. Not all values and ideals promoted by China, such as mutual benefits and cooperation without additional conditions, are fully abided. In situations where the quality of corporate governance is insufficient, the economy is weak and partnership conditions are not transparent, collaboration with China might lead to serious consequences for the LDCs. However, cooperation with the PRC is one of the few, if not the single, chances for many countries to escape extreme poverty. China clearly understands this situation and pragmatically pursuits its interests. An interesting implication of the cooperation between the LDCs-10 countries and China is a decrease in conflicts between the neighbouring LDCs in situations when cooperation with China requires involvement of a neighbour. This question is very topical for many landlocked LDCs frequently having difficulties with their neighbours. In this context, construction and operation by the PRC of the Djibouti-Ethiopia railroad contributed to their constructive relationship.

Table 7. Dynamics of the Indicators of the Socio-Economic Development of the LDCs-10 and China

\begin{tabular}{|c|c|c|c|c|c|c|c|}
\hline Country & $\begin{array}{c}\text { GDP per Capi- } \\
\text { ta, } 2015 / 18,{ }^{12} \\
\$ \text { Thousand }\end{array}$ & $\begin{array}{c}\text { Human } \\
\text { Develop- } \\
\text { ment Index, } \\
2015^{13} / 18,{ }^{14} \\
\text { Rank in the } \\
\text { World }\end{array}$ & $\begin{array}{c}\text { Corruption } \\
\text { Percep- } \\
\text { tion Index, } \\
2015 / 18,{ }^{15} \\
\text { Rank in the } \\
\text { World }\end{array}$ & $\begin{array}{c}\text { Democ- } \\
\text { racy Index, } \\
2015 / 18,{ }^{16} \\
\text { Rank in the } \\
\text { World }\end{array}$ & $\begin{array}{c}\text { Global } \\
\text { Competitive- } \\
\text { ness Index, } \\
2014 / 15- \\
2017 / 18,{ }^{17} \\
\text { Rank in the } \\
\text { World }\end{array}$ & $\begin{array}{c}\text { Gross } \\
\text { Capital } \\
\text { Formation, } \\
2015 / 17, \\
\% \text { GDP }^{18}\end{array}$ & $\begin{array}{c}\text { Unem- } \\
\text { ployment, } \\
2015 / 18,{ }^{19} \\
\% \text { of Total } \\
\text { Labour } \\
\text { Force }\end{array}$ \\
\hline Angola & $7,097 / 6,452$ & $149 / 147$ & $163 / 165$ & $131 / 123$ & $140 /-$ & $34.2 / 24.1$ & $7.3 / 7.3$ \\
\hline Bangladesh & $3,451 / 4,372$ & $142 / 136$ & $139 / 149$ & $86 / 88$ & $109 / 99$ & $28.9 / 30.5$ & $4.4 / 4.3$ \\
\hline Cambodia & $3,514 / 4,361$ & $143 / 146$ & $150 / 161$ & $113 / 125$ & $95 / 94$ & $22.5 / 22.9$ & $1.2 / 1.1$ \\
\hline DPRK & $696 / 685^{20}$ & - & $167 / 176$ & $167 / 167$ & $-1-$ & $-1-$ & $3.5 /-3.3$ \\
\hline $\begin{array}{l}\text { Dem. Rep. } \\
\text { of the Congo }\end{array}$ & $867 / 932$ & $176 / 176$ & $147 / 149$ & $157 / 165$ & $-/ 126$ & $18.5 / 25$ & $4.2 / 4.2$ \\
\hline Ethiopia & $1,622 / 2,022$ & $174 / 173$ & $102 / 114$ & $123 / 128$ & $118 / 108$ & $40.7 / 38.5$ & $2 / 1.8$ \\
\hline Myanmar & $5,372 / 6,674$ & $148 / 148$ & $147 / 132$ & $114 / 118$ & $134 / 131^{21}$ & $34.6 / 32.8$ & $0.8 / 1.6$ \\
\hline Sudan & $4,552 / 4,759$ & $167 / 167$ & $165 / 172$ & $151 / 155$ & $-1-$ & 16.6/18.9 & $13.2 / 12.9$ \\
\hline Tanzania & $2,791 / 3,227$ & $151 / 154$ & $117 / 99$ & $91 / 91$ & $121 / 113$ & $32.8 / 34$ & $2.1 / 1.9$ \\
\hline Zambia & $3,928 / 4,224$ & $139 / 144$ & $76 / 105$ & $73 / 86$ & $96 / 118$ & $\begin{array}{c}42.8 / 38.2 \\
(2016)\end{array}$ & $7.5 / 7.2$ \\
\hline China & $14,455 / 18,237$ & $90 / 86$ & $83 / 87$ & $136 / 130$ & $28 / 27$ & $45.6 / 44.3$ & $4.6 / 4.4$ \\
\hline
\end{tabular}

Sources: Compiled by the author.

${ }^{12}$ [World Bank, n. d., a].

${ }^{13}$ From 188 countries and territories [UNDP, 2015].

${ }^{14}$ From 189 countries and territories [UNDP, 2018].

${ }^{15}$ From 167 countries in 2015, and from 180 countries in 2018 [Transparency International, 2016; 2019].

${ }^{16}$ From 167 countries in 2015 and 2018 [The Economist Intelligence Unit, 2016; 2019].

${ }^{17}$ From 144 in 2014-15, and from 137 in 2017-18 [Schwab, 2014; 2017].

${ }^{18}$ [World Bank, n. d., b].

${ }^{19}$ [World Bank, n. d., c].

${ }^{20}[\mathrm{UN}$, n. d., f].

${ }^{21}$ [Schwab, 2015]. 
Serious asymmetry in the scope of interdependence in the cooperation between the LDCs10 countries and China cannot be overlooked. The LDCs-10 countries are significant exporters to China, in particular, supplying commodities. More than $\mathbf{8 \%}$ of the PRC's global imports of the LDCs-10's WPPGs comes from the LDCs-10. At the same time, the role of the LDCs-10 countries as importers of China's products is not significant. They account for just $\mathbf{0 . 9 \%}$ of the export volume of China's WPPGs, and $\mathbf{2 . 5 9 \%}$ of China's LPPGs.

Meanwhile, the important question of whether economic cooperation between the PRC and the LDCs-10 countries leads to complex enhancement of the situation in the interests of the PRC and the LDCs remains unanswered. Table 6 contains the dynamics of some indicators of socio-economic development of the LDCs-10 countries and China in 2015-18.

Using the above data, even given a lack of some information, it cannot be definitely claimed that the LDCs-10 countries, in developing active trade and investment partnership with the PRC, have seriously succeeded in resolving their key political, economic and social problems. We also cannot prove the negative effects of cooperation with China for improving indicators of the LDCs due to many externalities impacting situations.

However, it can be argued with reasonable certainty that cooperation with China, despite many opportunities and chances, is not a universal remedy to the challenges of implementing the SDGs. Partly, it is connected with ineffective models of economy and government, serious costs of doing business, high uncertainty, and many other problems not significantly influenced by a constructive cooperation with the PRC. Modest successes by LDCs in sustaining their development resulted from domestic factors. It is obvious when comparing their situation with the PRC, which despite a weak starting position, has succeeded in modernizing its economy and improving people's welfare. However, China faces new challenges to maintaining sustainable and dynamic development. The outcomes of Chinese policy will impact perspectives not only of the PRC but of dozens of countries and their populations.

\section{References}

Aleksandrova M.V. (2018) Tarifnoe i netarifnoe regulirovanie importa v KNR i ego vliyanie na vvoz tovarov iz Rossii [Tariff and Non-Tariff Regulation of Imports in China and Its Impact on the Import of Goods From Russia]. Kitaj v mirovoj i regional'noj politike. Istoriya i sovremennost' [China in World and Regional Politics: History and Modernity] (E.I. Safronova (ed.)). Moscow: IFE RAS (in Russian).

All Africa (2017). South Sudan: China-Built School Inaugurated in South Sudan, 16 January. Available at: https://allafrica.com/stories/201701160064.html (accessed 30 April 2018).

Asian Infrastructure Investment Bank (AIIB) (n. d.). Approved Projects. Available at: https://www.aiib.org/ en/projects/approved/index.html (accessed 10 September 2019).

Bdnews24.com (2019) Bangladesh Receives Record FDI in 2018, China Tops Investors List, 9 May. Available at: $\quad$ https://bdnews24.com/economy/2019/05/09/bangladesh-receives-record-fdi-in-2018-china-topsinvestors-list (accessed 20 October 2019).

Business Insider (2018). RAWBANK: Lone Congolese Bank to Sign the China-Africa Inter Bank Association Establishment Agreement. Available at: https://www.businessinsider.my/rawbank-lone-congolese-bank-tosign-the-china-africa-inter-bank-association-establishment-agreement (accessed 9 October 2019).

Cao D. (2019) BRI Brings New Concept, Mutual Benefit. China Daily, 26 April. Available at: https://www. chinadailyhk.com/articles/45/154/122/1556260866727.html (accessed 9 July 2019).

Challaney B. (2017) China's Debt-Trap Diplomacy. Project Syndicate, 23 January. Available at: https:// www.project-syndicate.org/commentary/china-one-belt-one-road-loans-debt-by-brahma-chellaney-201701?barrier=accesspaylog (accessed 25 May 2019). 
Chen J. (2019) Third-Party Model to Open More Paths on Belt and Road Route. China Daily, 17 April. Available at: https://eng.yidaiyilu.gov.cn/qwyw/rdxw/86108.htm (accessed 18 September 2019).

China-Africa Forum (FOCAC) (2019). Forum on China-Africa Cooperation Beijing Action Plan (2019-2021). Beijing, 12 September. Available at: https://focacsummit.mfa.gov.cn/eng/hyqk_1/t1594297.htm (accessed 18 September 2019).

China Civil Engineering Construction Corporation (CCECC) (2016). CCECC Signs Ethiopia-Djibouti Railway Operation and Management Project, 1 September. Available at: http://www.ccecc.com.cn/art/2016/9/1/ art_7753_1136443.html (accessed 20 March 2018).

China Development Bank (CDB) (2019). CDB Provides Over 50 billion USD of Investment and Financing for Africa. Available at: http://www.cdb.com.cn/English/xwzx_715/khdt/201902/t20190201_5875.html (accessed 9 July 2019).

Council for the Development of Cambodia (n. d.). Investment Trend. Available at: http://www. cambodiainvestment.gov.kh/why-invest-in-cambodia/investment-enviroment/investment-trend.html (accessed 20 August 2019).

Denisov I.E., Adamova D.L. (2017) Formuly vneshnej politiki Si Czin'pina: osnovnye osobennosti i problemy interpretacii [Xi Jinping's Foreign Policy Formulas: Main Features and Problems of Interpretation]. Kitaj $v$ mirovoj i regional'noj politike. Istoriya i sovremennost' [China in World and Regional Politics: History and Modernity] (E.I. Safronova (ed)). Moscow: IFE RAS (in Russian).

Directorate of Investment and Company Administration (DICA) (n. d.). Foreign Investment by Country. Available at: https://www.dica.gov.mm/en/topic/foreign-investment-country?page $=2$ (accessed 10 September 2019).

Ernst \& Young (EY) (2018). How Does Geopolitical Dynamics Affect Future China Overseas Investment? China Go Abroad (8th Issue), November. Available at: https://www.ey.com/Publication/vwLUAssets/eychina-overseas-investment-report-issue-8-en/\$FILE/ey-china-overseas-investment-report-issue-8-en.pdf (accessed 20 September 2019).

Global Trade Alert (n. d.). Independent Monitoring of Policies That Affect World Commerce. Available at: https://www.globaltradealert.org (accessed 20 September 2019).

Gunter F.R. (2017) Why China Lost About $\$ 3.8$ Trillion to Capital Flight in the Last Decade. Forbes, 22 February. Available at: http://www.globaltimes.cn/content/956623.shtml (accessed 9 September 2019).

Horn S., Reinhart C., Trebesch C. (2019) China’s Overseas Lending. Kiel Working Paper No 2132, Kiel Institute for the World Economy. Available at: https://www.ifw-kiel.de/fileadmin/Dateiverwaltung/IfW-Publications/ Christoph_Trebesch/KWP_2132.pdf

Information Office of the State Council, the People's Republic of China (2011). China's Foreign Aid. White Paper. Available at: http://english.www.gov.cn/archive/white_paper/2014/09/09/content_281474986284620. htm.

Information Office of the State Council, the People's Republic of China (2014). China's Foreign Aid White Paper. Available at: http://english.www.gov.cn/archive/white_paper/2014/08/23/content_281474982986592. htm.

Larionova M., Safonkina E. (2018) The First Five Decades of Cooperation for Development: Actors, Achievements and Challenges. International Organisations Research Journal, vol. 13, no 4, pp. 96-136. Available at: https://doi.org/10.17323/1996-7845-2018-04-05.

Mardashev A.A. (2011) Kitajskaya model' pomoshchi mezhdunarodnomu razvitiyu [The Chinese Model of Assistance to International Development]. Vestnik MGIMO Universiteta [Bulletin of MGIMO University], no 6 (in Russian).

Mikhnevich S.V. (2017) Kuda vedet nas novyj SHelkovyj put'? [Where Is the New Silk Road Leading Us?]. Novosti ATR [Asia Pacific News Brief], vol. 2, no 7. Available at: www.aprcenter.ru/images/ART_4.pdf (accessed 20 October 2019) (in Russian).

Mikhnevich S.V. (2019) 2-j Mezhdunarodnyj forum Poyasa i puti: kuda dal'she pojdet flagmanskaya mezhdunarodnaya iniciativa KNR? [Second Belt and Road Forum for International Cooperation: Where Will China's Flagship International Initiative Go Next?]. CIIR RANEPA. Available at: https://www.ranepa. 
$\mathrm{ru} /$ ciir/expert-opinion/2-j-mezhdunarodnyj-forum-poyasa-i-puti-kuda-dalshe-pojdet-flagmanskayamezhdunarodnaya-iniciativa-knr (accessed 18 September 2019) (in Russian).

Ministry of Commerce of the People's Republic of China (2015). Administrative Measures for Foreign Technical Assistance Projects (Trial). Order No 5 (in Chinese).

Ministry of Finance of the People's Republic of China (2017). Notice of the State Council Tariff Commission on the 2018 Tariff Adjustment Plan. Commission on Customs Tariffs of the State Council of the PRC, Inland Revenue Commission No 27. Available at: http://gss.mof.gov.cn/zhengwuxinxi/zhengcefabu/201712/ t20171215_2777552.html (accessed 18 September 2019) (in Chinese).

Ministry of Finance of the People's Republic of China (2018). Notice of the State Council Customs Tariff Commission on the Adjustment Plan for the Temporary Import and Export Tax Rates in 2019. Commission on Customs Tariffs of the State Council of the PRC, Tax Commission No 65 Available at: http://gss.mof.gov. cn/zhengwuxinxi/zhengcefabu/201812/t20181221_3101662.html (accessed 18 September 2019) (in Chinese).

Ministry of Foreign Affairs of the People's Republic of China (2016). China's Position Paper on the Implementation of the 2030 Agenda for Sustainable Development. Communiqué, 22 April. Available at: http:// www.fmprc.gov.cn/mfa_eng/wjdt_665385/2649_665393/t1357701.shtml (accessed 18 September 2019).

Moramudali U. (2019) Is Sri Lanka Really a Victim of China's 'Debt Trap'? The Diplomat, 14 May. Available at: https://thediplomat.com/2019/05/is-sri-lanka-really-a-victim-of-chinas-debt-trap/ (accessed 25 May 2019).

National Development and Reform Commission of the People's Republic of China (NDRC) (2017). Administrative Measures for Enterprise Outbound Investment. Decree No 11. Available at: https://www.ndrc. gov.cn/fggz/lywzjw/zcfg/201712/t20171226_1047050.html (accessed 9 September 2019) (in Chinese).

National Development and Reform Commission of the People's Republic of China (NDRC) (2019). Report on the Implementation of the 2018 Plan for National Economic and Social Development and on the 2019 Draft Plan for National Economic and Social Development Delivered at the Second Session of the Thirteenth National People's Congress. Beijing, 5 March.

Organisation for Economic Co-operation and Development (OECD) (n. d.) Agricultural Support. Available at: https://data.oecd.org/agrpolicy/agricultural-support.htm (accessed 20 May 2019).

Office of the Leading Group for Promoting the Belt and Road Initiative (2019). The Belt and Road Initiative: Progress, Contributions and Prospects. Available at: https://eng.yidaiyilu.gov.cn/zchj/qwfb/86739.htm (accessed 20 September 2019).

Office of the State Council of the People's Republic of China (2017). Notice of the General Office of the State Council on the Guiding Opinions of the Ministry of Commerce of the National Development and Reform Commission and the Ministry of Foreign Affairs of the People's Bank of China on Further Guiding and Regulating the Direction of Overseas Investment. State Council No 74. Available at: http://www.gov.cn/ zhengce/content/2017-08/18/content_5218665.htm (accessed 9 September 2019) (in Chinese).

Pankova A.S., Mikhnevich S.V. (2018) Politiko-ekonomicheskie aspekty razvitiya Naimenee razvityh stran [Political and Economic Aspects of the Development of the Least Developed Countries]. Aktual'nye problemy Evropy [Actual Problems of Europe], no 1. pp. 122-46 (in Russian).

Radio Free Asia (RFA) (2017). Xi Jinping Proposes That China's Foreign Aid Must Be More Reasonable in the Future, 9 February. Available at: https://www.rfa.org/mandarin/yataibaodao/junshiwaijiao/nu-0209 2017164129.html (accessed 12 March 2019) (in Chinese).

Railway Gazette International (2016). Ethiopia-Djibouti Railway Inaugurated. 5 October. Available at: https:// www.railwaygazette.com/news/infrastructure/single-view/view/ethiopia-djibouti-railway-inaugurated.html (accessed 20 April 2018).

Ren Q., Zhou W. (2017). Contrary to Western Countries: China's Foreign Aid Steadily Increases. Xinhua News Agency, 23 March. Available at: http://xinhua-rss.zhongguowangshi.com/13694/622380394845431009/1687327.html (accessed 18 March 2018) (in Chinese).

Reuters (2020). China's 2019 Foreign Direct Investment Grew Most in Two Years, but Outbound Investment Fell 6 Per Cent. 21 January. Available at: https://www.scmp.com/economy/china-economy/article/3046958/ chinas-2019-foreign-direct-investment-58-cent-outbound (accessed 20 January 2020). 
Safronova E.I. (2018) Kitaj i razvivayushchijsya mir: koncepcii i aktual'naya praktika otnoshenij na primere Afriki i Latinskoj Ameriki [China and the Developing World: Concepts and Actual Practice of Relations on the Example of Africa and Latin America]. Moscow: ID FORUM (in Russian).

Schwab K. (2014) The Global Competitiveness Report 2014-2015. World Economic Forum Insight Report. Available at: http://www3.weforum.org/docs/WEF_GlobalCompetitivenessReport_2014-15.pdf (accessed 20 January 2020).

Schwab K. (2015) The Global Competitiveness Report 2015-2016. World Economic Forum Insight Report. Available at: http://www3.weforum.org/docs/gcr/2015-2016/Global_Competitiveness_Report_2015-2016.pdf (accessed 20 January 2020).

Schwab K. (2017) The Global Competitiveness Report 2017-2018. World Economic Forum Insight Report. Available at: http://www3.weforum.org/docs/GCR2017-2018/05FullReport/TheGlobalCompetitivenessRep ort2017-2018.pdf (accessed 20 January 2020).

Solomon S. (2018) Zambia Continues to Borrow as China Debt Concerns Rise. VOA News, 11 September. Available at: https://www.voanews.com/africa/zambia-continues-borrow-china-debt-concerns-rise (accessed 20 September 2018).

The Economist Intelligence Unit (2016). Democracy Index 2015: Democracy in an Age of Anxiety. Available at: https://www.eiu.com/public/topical_report.aspx?campaignid=DemocracyIndex2015 (accessed 20 January 2019).

The Economist Intelligence Unit (2019). Democracy Index 2018: Me Too? Political Participation, Protest and Democracy Available at: https://275rzylul4252pt1hv2dqyuf-wpengine.netdna-ssl.com/wp-content/ uploads/2019/01/Democracy_Index_2018.pdf (accessed 20 January 2019).

Transparency International (2016). Corruption Perceptions Index 2015. Available at: https://www.transparency. org/whatwedo/publication/cpi_2015 (accessed 1 September 2019).

Transparency International (2019). Corruption Perceptions Index 2018. Available at: https://www.transparency. org/whatwedo/publication/corruption_perceptions_index_2018 (accessed 1 September 2019).

Tumfweko (2017). Kampamba: TopStar Company Owns Majority 60\% Shares in ZNBC. 13 February. Available at: https://tumfweko.com/2017/02/13/kampamba-topstar-company-owns-majority-60-shares-inznbc/ (accessed 7 September 2018).

United Nations (UN) (n. d., a). List of Least Developed Countries (As of December 2018). Committee for Development Policy. Available at: https://www.un.org/development/desa/dpad/wp-content/uploads/ sites/45/publication/ldc_list.pdf (accessed 15 August 2019).

United Nations (UN) (n. d., b). SDG Indicators. Available at: https://unstats.un.org/sdgs/indicators/database/ (accessed 20 September 2019).

United Nations (UN) (n. d., c). China's Rules of Origin for LDCs. LDC Portal: International Support Measures for Least Developed Countries. Available at: https://www.un.org/ldcportal/new-chinese-measureson-rules-of-origin-of-imported-goods-from-ldcs/ (accessed 23 April 2018).

United Nations (UN) (n. d., d). Preferential Market Access for Goods. LDC Portal: International Support Measures for Least Developed Countries. Available at: https://www.un.org/ldcportal/preferential-marketaccess-for-goods/ (accessed 9 September 2019).

United Nations (UN) (n. d., e). Preferential Market Access: China's DFQF Scheme for LDC Products. LDC Portal: International Support Measures for Least Developed Countries. Available at: https://www.un.org/ ldcportal/preferential-market-access-chinas-dfqf-scheme-for-ldc-products/ (accessed 9 September 2019).

United Nations (n. d., f). Country Profile: Democratic People's Republic of Korea. UN Statistics Office. Available at: http://data.un.org/en/iso/kp.html (accessed 10 September 2019).

United Nations (UN) (2015) Transforming Our World: The 2030 Agenda for Sustainable Development. General Assembly Resolution A/RES/70/1. Available at: https://undocs.org/A/RES/70/1.

United Nations Conference on Trade and Development (UNCTAD) (n. d.). UNCTAD Stat. Available at: https://unctadstat.unctad.org/wds/ReportFolders/reportFolders.aspx?sCS_ChosenLang=en (accessed 20 September 2019). 
United Nations Conference on Trade and Development (UNCTAD) (2016). G20 Policies and Export Performance of Least Developed Countries. Policy Issues in International Trade and Commodities Research Study Series No 75. Available at: https://unctad.org/en/PublicationsLibrary/itcdtab77_en.pdf (accessed 20 September 2019).

United Nations Conference on Trade and Development (UNCTAD) (2018). World Investment Report: Investment and New Industrial Policies. Available at: https://unctad.org/en/PublicationsLibrary/wir2018_ en.pdf (accessed 20 September 2019).

United Nations Conference on Trade and Development (UNCTAD) (2019a). Least Developed Countries Report: The Present and Future of External Development Finance: Old Dependencies, New Challenges. Available at: https://unctad.org/en/PublicationsLibrary/ldcr2019_en.pdf (accessed 20 September 2019).

United Nations Conference on Trade and Development (UNCTAD) (2019b). World Investment Report: Special Economic Zones. Available at: https://unctad.org/en/PublicationsLibrary/wir2019_en.pdf (accessed 20 September 2019).

United Nations Development Programme (UNDP) (2015). Human Development Report 2015: Work for Human Development. Available at: http://hdr.undp.org/en/content/human-development-report-2015 (accessed 1 September 2019).

United Nations Development Programme (UNDP) (2018). 2018 Statistical Update: Human Development Indices and Indicators. Available at: http://hdr.undp.org/en/content/human-development-indices-indicators2018-statistical-update (accessed 1 September 2019).

Wang K., Huang M., Tang X. (2018) China's NDRC Issued New Outbound Investment Rules. China Law Insight, 18 January. Available at: https:/www.chinalawinsight.com/2018/01/articles/foreign-investment/ chinas-ndrc-issued-new-outbound-investment-rules/\#_ftn2 (accessed 9 September 2019).

Weizhen T. (2019) China's Loans to Other Countries Are Causing 'Hidden' Debt: That May Be a Problem. CNBC, 11 June. Available at: https://www.cnbc.com/2019/06/12/chinas-loans-causing-hidden-debt-risk-toeconomies.html (accessed 10 July 2019).

World Bank (n. d., a). GDP Per Capita, PPP (Current International \$). Available at: https://data.worldbank. org/indicator/NY.GDP.PCAP.PP.CD? end=2018\&start=2015\&view= chart (accessed 1 September 2019).

World Bank (n. d., b). Gross Capital Formation (\% of GDP). Available at: https://data.worldbank.org/ indicator/NE.GDI.TOTL.ZS?view=chart (accessed 1 September 2019).

World Bank (n. d., c). Unemployment, Total (\% of Total Labor Force) (Modeled ILO Estimate). Available at: https://data.worldbank.org/indicator/SL.UEM.TOTL.ZS?view=chart (accessed 1 September 2019).

World Bank (n. d., d). Tariff Rate, Applied, Weighted Mean, All Products (\%): China, United States, OECD Members, European Union. Available at: https://data.worldbank.org/indicator/TM.TAX.MRCH.WM.AR. ZS? end $=2017$ \&locations $=$ CN-US-OE-EU\&start $=2015 \&$ view $=$ chart $($ accessed 20 September 2019) .

World Trade Organization (WTO) (n. d., a). Regional Trade Agreements Database. Available at: http://rtais. wto.org/UI/PublicMaintainRTAHome.aspx (accessed 9 July 2019).

World Trade Organization (WTO) (n. d., b). Rate of TFA Implementation Commitment. Trade Facilitation Agreement Database. Available at: https://tfadatabase.org/members/china (accessed 9 September 2019).

World Trade Organization (WTO) (2018). China Donates USD 1 Million to Support Implementation of Trade Facilitation Agreement. Available at: https://tfafacility.org/china-donates-usd-1-million-supportimplementation-trade-facilitation-agreement (accessed 9 September 2019).

World Trade Organization (WTO) (2019). Sub-Committee on Least Developed Countries: Market Access for Products and Services of Export Interest to Least Developed Countries: Note by the Secretariat. WT/COMTD/ $\mathrm{LDC} / \mathrm{W} / 67$.

Xinhua News Agency (2015). Xi Announces 10 Major China-Africa Cooperation Plans for Coming 3 Years. Available at: http://www.globaltimes.cn/content/956623.shtml (accessed 2 March 2020).

Xinhua News Agency (2019). Cambodia Attracts 7.9 Bln USD Investment From China in Nearly 4 Years: Senior Official. 11 October. Available at: http://www.xinhuanet.com/english/2019-10/11/c_138462725.htm (accessed 20 October 2019). 
Zhao L. (2019) Novoe izmerenie "Poyasa i puti" v doklade o rabote pravitel'stva [A New Dimension of "Belt and Road": An Analysis of the Government Report]. Zhurnal "Kitaj" [China Journal], 1 April. Available at: http://www.kitaichina.com/rjingji/201904/t20190401_800163856.html (accessed 20 October 2019) (in Russian).

Zheng Y. (2016) China's Aid and Investment in Africa: A Viable Solution to International Development? Available at: https://www.hhs.se/contentassets/bc7089cd2c364b2cae4c287184ad743b/yu-zheng---chinasaid-and-investment-in-africa-.pdf (accessed 18 September 2019).

Zhou J., Zhang Y. (2018) China International Development Cooperation Agency Inaugurated. China Daily, 18 April. Available at: http://www.chinadaily.com.cn/a/201804/18/WS5ad72297a3105cdcf651915e.html (accessed 30 May 2018). 


\section{Annex 1. Priority Product Groups of Exports by LDCs-10 Countries to the World Market}

\begin{tabular}{|c|c|}
\hline \multicolumn{2}{|l|}{ Angola } \\
\hline Product Groups & $\begin{array}{l}\text { Total Exports to the World Market, 2015-17, } \\
\text { \$ Thousand }\end{array}$ \\
\hline Petroleum, petroleum products and related materials & $92,081,845.97$ \\
\hline Crude fertilizers other than division 56 , and crude minerals & $2,733,115.4$ \\
\hline Fish, crustaceans, molluscs and preparations thereof & $160,717.89$ \\
\hline Cork and wood & $21,351.46$ \\
\hline Coffee, tea, cocoa, spices, and manufactures thereof & $3,163.58$ \\
\hline $\begin{array}{l}\text { Total exports/share of the five WPPGs in total exports/share of the PRC } \\
\text { in the WPPGs' exports/five WPPGs' export intensity (\% of GDP) }\end{array}$ & $\$ 95,000,194.3 / 100 \% / 44.69 \% / 27.25 \%$ \\
\hline \multicolumn{2}{|l|}{ Bangladesh } \\
\hline Product Groups & $\begin{array}{l}\text { Total Exports to the World Market, 2015-17, } \\
\text { \$ Thousand }\end{array}$ \\
\hline Articles of apparel \& clothing accessories & $84,828,664.78$ \\
\hline Textile yarn and related products & $5,018,884.58$ \\
\hline Footwear & $2,229,253.71$ \\
\hline Fish, crustaceans, molluscs and preparations thereof & $1,859,596.27$ \\
\hline Leather, leather manufactures and dressed furskins & $990,166.79$ \\
\hline $\begin{array}{l}\text { Total exports/share of the five WPPGs in total exports/share of the PRC } \\
\text { in the WPPGs' exports/five WPPGs' export intensity (\% of GDP) }\end{array}$ & $\$ 101,538,390.9 / 93.49 \% / 2.05 \% / 13.4 \%$ \\
\hline \multicolumn{2}{|l|}{ Cambodia } \\
\hline Product Groups & $\begin{array}{l}\text { Total Exports to the World Market, 2015-17, } \\
\text { \$ Thousand }\end{array}$ \\
\hline Articles of apparel \& clothing accessories & $19,278,418.15$ \\
\hline Footwear & $2,906,281.88$ \\
\hline Gold, non-monetary (excluding gold ores and concentrates) & $1,030,438.04$ \\
\hline Vegetables and fruits & $939,917.92$ \\
\hline Road vehicles & $820,265.52$ \\
\hline $\begin{array}{l}\text { Total exports/share of the five WPPGs in total exports/share of the PRC } \\
\text { in the WPPGs' exports/five WPPGs' export intensity (\% of GDP) }\end{array}$ & $\$ 30,700,759.99 / 81.35 \% / 2.26 \% / 44 \%$ \\
\hline \multicolumn{2}{|c|}{ Democratic People's Republic of Korea } \\
\hline Product Groups & $\begin{array}{l}\text { Total Exports to the World Market, 2015-17, } \\
\text { \$ Thousand }\end{array}$ \\
\hline Coal, coke and briquettes & $3,041,697.53$ \\
\hline Articles of apparel \& clothing accessories & $2,184,068.92$ \\
\hline Metalliferous ores and metal scrap & $683,771.36$ \\
\hline Fish, crustaceans, molluscs and preparations thereof & $512,532.45$ \\
\hline Iron and steel & $284,709.32$ \\
\hline $\begin{array}{l}\text { Total exports/share of the five WPPGs in total exports/share of the PRC } \\
\text { in the WPPGs' exports/five WPPGs' export intensity (\% of GDP) }\end{array}$ & $\$ 7,983,538.96 / 84.01 \% / 97.14 \% / 7.54 \%$ \\
\hline
\end{tabular}




\begin{tabular}{|c|c|}
\hline \multicolumn{2}{|c|}{ Democratic Republic of the Congo } \\
\hline Product Groups & $\begin{array}{l}\text { Total Exports to the World Market, 2015-17, } \\
\text { \$ Thousand }\end{array}$ \\
\hline Non-ferrous metals & $11,243,828.52$ \\
\hline Metalliferous ores and metal scrap & $2,851,414.69$ \\
\hline Non-metallic mineral manufactures, n.e.s. & $1,266,721.54$ \\
\hline Inorganic chemicals & $954,968.98$ \\
\hline Petroleum, petroleum products and related materials & $899,466.35$ \\
\hline $\begin{array}{l}\text { Total exports/share of the five WPPGs in total exports/share of the PRC } \\
\text { in the WPPGs' exports/five WPPGs' export intensity (\% of GDP) }\end{array}$ & $\$ 19,100,000 / 90.13 \% / 44.47 \% / 19.2 \%$ \\
\hline \multicolumn{2}{|l|}{ Ethiopia } \\
\hline Product Groups & $\begin{array}{l}\text { Total Exports to the World Market, 2015-17, } \\
\text { \$ Thousand }\end{array}$ \\
\hline Coffee, tea, cocoa, spices, and manufactures thereof & 2489236.62 \\
\hline Vegetables and fruits & $1,448,863.67$ \\
\hline Oil seeds and oleaginous fruits & $1,141,852.75$ \\
\hline Crude animal and vegetable materials, n.e.s. & $773,876.8$ \\
\hline Gold, non-monetary (excluding gold ores and concentrates) & $757,898.09$ \\
\hline $\begin{array}{l}\text { Total exports/share of the five WPPGs in total exports/share of the PRC } \\
\text { in the WPPGs' exports/five WPPGs' export intensity (\% of GDP) }\end{array}$ & $\$ 9,130,909.8 / 72.4 \% / 10.88 \% / 3.03 \%$ \\
\hline \multicolumn{2}{|l|}{ Myanmar } \\
\hline Product Groups & $\begin{array}{l}\text { Total Exports to the World Market, 2015-17, } \\
\text { \$ Thousand }\end{array}$ \\
\hline Gas, natural and manufactured & $11,359,928.53$ \\
\hline Articles of apparel \& clothing accessories & $4,988,214.59$ \\
\hline Vegetables and fruits & $4,414,071.23$ \\
\hline Cereals and cereal preparations & $3,014,489.78$ \\
\hline Sugar, sugar preparations and honey & $2,175,260.42$ \\
\hline $\begin{array}{l}\text { Total exports/share of the five WPPGs in total exports/share of the PRC } \\
\text { in the WPPGs' exports/five WPPGs' export intensity (\% of GDP) }\end{array}$ & $\$ 37,708,627.94 / 70.91 \% / 39.16 \% / 13.53 \%$ \\
\hline \multicolumn{2}{|l|}{ Sudan } \\
\hline Product Groups & $\begin{array}{l}\text { Total Exports to the World Market, 2015-17, } \\
\text { \$ Thousand }\end{array}$ \\
\hline Gold, non-monetary (excluding gold ores and concentrates) & $3,810,571.32$ \\
\hline Petroleum, petroleum products and related materials & $1,952,123.20$ \\
\hline Live animals other than animals of division 03 & $1,553,416.88$ \\
\hline Oil seeds and oleaginous fruits & $1,427,425.29$ \\
\hline Crude animal and vegetable materials, n.e.s. & $238,095.02$ \\
\hline $\begin{array}{l}\text { Total exports/share of the five WPPGs in total exports/share of the PRC } \\
\text { in the WPPGs' exports/five WPPGs' export intensity (\% of GDP) }\end{array}$ & $\$ 10,556,201.86 / 85.08 \% / 17.82 \% / 2.97 \%$ \\
\hline \multicolumn{2}{|l|}{ Tanzania } \\
\hline Product Groups & $\begin{array}{l}\text { Total Exports to the World Market, 2015-17, } \\
\text { \$ Thousand }\end{array}$ \\
\hline Gold, non-monetary (excluding gold ores and concentrates) & $4,087,335.06$ \\
\hline Vegetables and fruits & $1,792,105.19$ \\
\hline
\end{tabular}




\begin{tabular}{|l|l|}
\hline Tobacco and tobacco manufactures & $1,006,111.12$ \\
\hline Non-metallic mineral manufactures, n.e.s. & $892,078.71$ \\
\hline Metalliferous ores and metal scrap & $839,188.88$ \\
\hline $\begin{array}{l}\text { Total exports/share of the five WPPGs in total exports/share of the PRC } \\
\text { in the WPPGs' exports/five WPPGs' export intensity (\% of GDP) }\end{array}$ & $\$ 13,809,707.88 / 47.43 \% / 4.02 \% / 4.74 \%$ \\
\hline \multicolumn{1}{|c|}{ Zambia } & Total Exports to the World Market, 2015-17, \\
\hline \multicolumn{2}{|c|}{ \$ Thousand } \\
\hline Non-ferrous metals Groups & $14,881,235.87$ \\
\hline Non-metallic mineral manufactures, n.e.s. & $718,259.94$ \\
\hline Cereals and cereal preparations & $695,421.63$ \\
\hline Tobacco and tobacco manufactures & $583,948.94$ \\
\hline Sugar, sugar preparations and honey & $482,044.24$ \\
\hline $\begin{array}{l}\text { Total exports/share of the five WPPGs in total exports/share of the PRC } \\
\text { in the WPPGs' exports/five WPPGs' export intensity (\% of GDP) }\end{array}$ & $\$ 21,754509.4 / 79.8 \% / 26.38 \% / 24.98 \%$ \\
\hline
\end{tabular}

